\title{
NON-BANK CONSUMER CREDITING TRENDS IN LATVIA
}

\author{
Gunita Mazure \\ Latvia University of Agriculture \\ gunita.mazure@1lu.lv
}

\begin{abstract}
Non-bank crediting has become popular in Latvia as well as in other European countries due to various economic and social factors. Since the banks in recent years have introduced much stricter lending conditions, non-bank crediting sector has experienced a significant increase not only in Latvia but also in other European and world countries. Non-bank crediting market actively began to develop through a wide promotion of consumer credits in the major mass media; thus, creating human interest in the availability of fast and easy processable credits. Non-bank credit companies without customer deposits have transformed the present credit market, since a number of new players entered the market testing new business and crediting models and providing solutions to credit-challenged customers. The research aim is to study the non-bank consumer crediting trends in Latvia and it employs a monographic descriptive method as well as the methods of analysis and synthesis and graphics. The research results demonstrate that the popularity of non-bank credits is still growing among consumers, since the total amounts of non-bank credits disbursed for the first time have increased by EUR 116.61 million or 33.18\% for the period 2012-2015 with distance credits being the most demanded credit type accounting for approximately $40 \%$ of all non-bank credits. Non-bank credit market is saturated and there is a fierce competition between non-bank crediting companies in terms of interest rates, crediting conditions and other factors.
\end{abstract}

Key words: non-bank credits, consumers, annual percentage rate of charge.

\section{Introduction}

Non-bank consumer crediting is a relatively new type of crediting in Latvia, since the first short-term loans have been disbursed right before the financial crisis in 2008. Simultaneously with the rapid development of Internet and changing habits of the people in the use of financial services, the non-bank crediting sector has experienced both a fast growth and high demand as well as it has faced many challenges related with the government intention to control the operation of non-bank services. In 2007, the first companies started to offer first distance credits. The service gained great popularity and new market players appeared to offer new and new types of crediting. The fact that the sector was not specifically regulated and any company with the minimum share capital of EUR 2845.6 might become a non-bank creditor facilitated the expansion of primarily distance crediting among the population. After the financial crisis, some researchers admitted that non-bank crediting sector called for wider and more intensive financial supervision (Gambacort \& Marques-Ibanez, 2011). Also, Romanian scientists Mirea and Aivaz (Mirea \& Aivaz 2014) have expressed a similar opinion that "the economic crisis has led to a major shift in thinking, i.e. the habit of an accelerated loan growth has been replaced by an accelerated decrease and by the decline of confidence in the banking system'. The resumption of growth in 2013 has led to the need for the banking system in Romania and other countries to find, as soon as possible, an appropriate structure of loans, in order to continue without worries the crediting of reliable customers (households and economic agents) (Mirea \& Aivaz 2014). Such researchers as Reifner, ClercRenaud, Knobloch and Robert Scott, Glennon have also studied different aspects related with interest rate restrictions and commercial lending distance issues (Reifner et al., 2010; Robert et al., 2008).

At present, the situation has changed - consumers recognise that the non-bank crediting is a modern tool and solution for receiving small loans. In addition, it is simpler and faster compared with bank crediting. The market is harmonised, and the companies operating in the non-bank crediting sector not only initiate new measures directed at the protection of customers but through various selfregulation mechanisms they contribute to a credible, socially responsible and long-term cooperation aimed lending practice; thus, improving the provision of credit services. Similar experience is observed also in other countries as Jagtiani and Lemieux (Jagtiani \& Lemieux, 2016) analysing small business lending in the USA emphasise that 'nonbank and alternative creditors have begun to compete with banks by introducing sophisticated technologies and new underwriting methods'.

The still existing high demand for non-bank consumer credits has determined the research hypothesis: non-bank consumer crediting is a demanded crediting instrument in Latvia; consequently the research aim is to study the non-bank consumer crediting trends in Latvia. The following research tasks are advanced to reach the set aim: 1) to give a brief insight into the regulatory requirements for non-bank crediting sector; 2) to analyse types and dynamics of non-bank crediting trends; and 3) to describe the calculation and essence of the annual percentage rate of charge. The analysis covers the period of 2012 - 2015, in some cases the years 2013 2015, since the Consumer Rights Protection Centre of 
Latvia has started to compile information on non-bank consumer credits only from 2013.

\section{Materials and Methods}

The information compiled by the European Commission, the Consumer Rights Protection Centre of Latvia, regulatory enactments of the Republic of Latvia, scientific publications of foreign and national researchers, and other materials have been used for the purpose of the study. The research is mainly based on the monographic descriptive method as well as the methods of analysis and synthesis are used to study the problem elements and synthesise coherencies or formulate regularities.

\section{Results and Discussion}

\section{Regulation of non-bank crediting sector}

Way to a legislatively aligned business environment started in 2011 after the introduction of the requirement for licensing of non-bank crediting companies. The amendments to the "Consumer Rights Protection Law" prescribed that only capital companies having received a special permit (licence) may provide credit services to consumers (Parliament..., 1999). The licence is issued by the Consumer Rights Protection Centre for one year. The companies which did not receive a licence were not allowed to enter into new contracts with consumers; they could only continue serving the existing contracts. Therefore, a high standard for the entry into business was determined along with the introduction of licensing, so companies not being oriented towards a long-term business dropped out. The amount of the state fee for the issuance of a licence is EUR 71 140, while for the re-registration it is EUR 14225 (Cabinet Regulation, 2011). In addition, the license can be obtained only by companies whose paid-up share capital is at least EUR 425000. Certain other requirements, such as not suspicious laundering, compliance with the Consumer Rights Protection Law, monitoring of credit allocation and data protection, are prescribed for consumer crediting companies. Before the introduction of the license fee and surveillance measures the market comprised about 77 non-bank consumer crediting companies; yet in 2015 only 55 capital companies hold a valid license. A major role in the market self-regulation is played by Latvian Association of Alternative Financial Services (former Latvian Association of Non-bank Creditors). The association unites non-bank crediting companies providing various financial services to the population. In early 2013, the association members signed the Best Practice Standard with a commitment to take additional measures to protect borrowers. The agreement also provides the promotion of responsible long-term business environment.
One of the recent amendments to the enactments regulating the non-bank crediting sector prescribes that it is prohibited to enter into a consumer credit contract in the time period from 23.00 o'clock to 7.00 o'clock, unless more strict restrictions for provisions of the consumer credit service are provided for in the laws and regulations regarding consumer credit (Cabinet Regulation, 2016).

\section{Types and dynamics of non-bank crediting trends}

Nowadays, non-bank credit companies without customer deposits are transforming the credit market. A number of new players have entered the market testing new business and crediting models and providing solutions to credit-challenged customers. In Latvia, non-bank lenders offer five types of non-bank credits:

- mortgage non-bank loans - loans for purchasing of real estate or loans the repayments of which are secured by a mortgage on immovable property. Non-bank mortgage loans are mainly provided for the purchase, improvement, repair or construction of housing premises as well as larger procurements. Loan repayment period can range from a few months to several decades. Loan amount depends on the collateral and the customer's ability to make monthly loan payments;

- leasing and another loan secured with a vehicle or other property (except real estate) - financial leases for the purchase of a vehicle or another object (excluding real estate) or lease (operating lease) or credit agreements, the repayment of which is secured by the collateral of purchased vehicle or another object (excluding real estate); this type of crediting includes also a reverse lease and credit agreements secured with a commercial pledge of a car;

- consumption credits - credit agreements under which a credit is granted for the financing of consumption and which are concluded at the presence of both parties, for example, credits for the purchase of certain goods and services, and other credits;

- distance credits - credit agreements under which the credit is granted for the financing of consumption and which are concluded via the Internet, telecommunications or other types of distance communication means (referred to as fast credit), no collateral required;

- loans against pledge of movable property credit agreements under which the loan is issued to finance consumption and which are disbursed against a movable collateral, the consumer's liability is limited only to the 


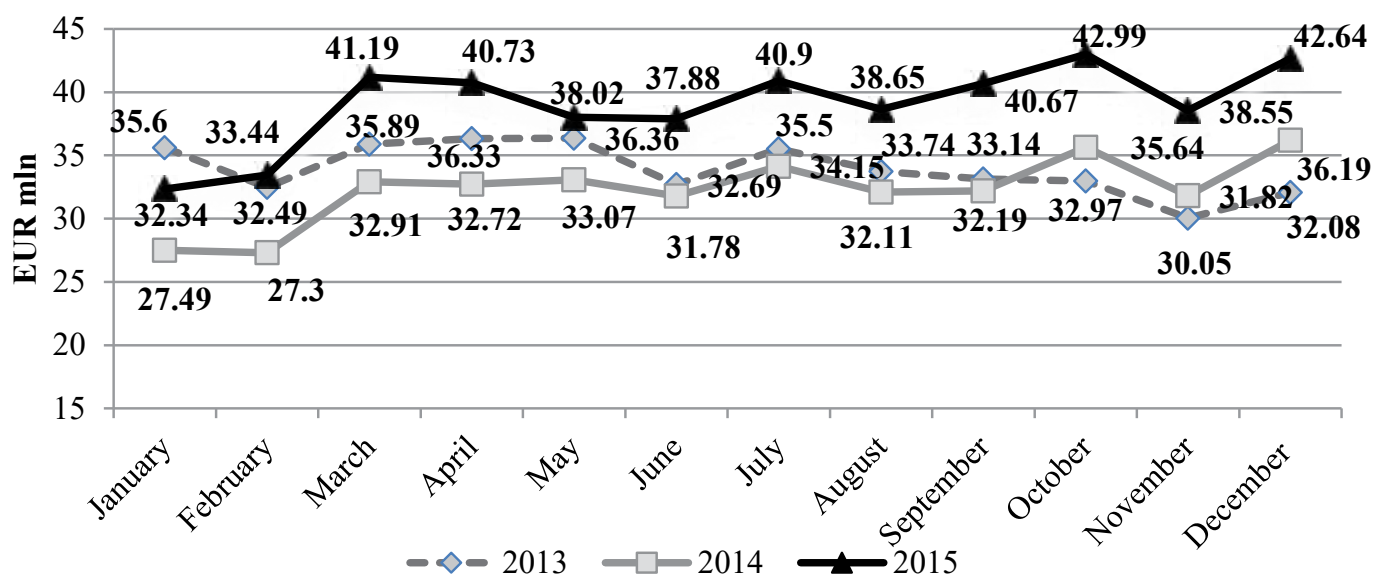

Source: author's construction based on Patērētāju tiesību ..., 2016.

Figure 1. Total amounts of credits disbursed for the first time by non-bank credit companies of Latvia between 2013 and 2015, EUR mln.

mortgaged property and loan amount depends on the collateral value (pawn loans).

The general tendencies show that non-bank credits still earn popularity among consumers, since the total amounts of non-bank credits disbursed for the first time have increased for the period 2013 - 2015 (Figure 1).

The largest amounts of credits are disbursed in 2015, when they amounted to EUR 468.01 million; credit amounts have grown by EUR 80.63 million or $20.81 \%$ compared with the previous year. Figure 1 reflects credit amount fluctuations by months allowing to conclude that cyclical trends are similar for the years 2014 and 2015 contrary to 2013. This means that the largest amounts in 2014 and 2015 were disbursed in December (EUR $36.19 \mathrm{mln}$ and EUR $42.64 \mathrm{mln}$ respectively), while the smallest ones in January (EUR $27.49 \mathrm{mln}$ and EUR $32.34 \mathrm{mln}$ respectively). The necessity for additional and easily receivable financial resources to cover the expenses for Christmas and New Year's holidays may explain such tendencies. The smallest amounts required in January may signal on the precaution of consumers at the beginning of the year. However, the year 2013 displays a different scene, i.e. the largest amounts are received in May (EUR $36.36 \mathrm{mln}$ ) and the smallest ones in November (EUR $30.05 \mathrm{mln}$ ). Here, the explanation may be related with the upcoming introduction of euro currency in 2014. The breakdown of disbursed credits by their types (Figure 2) demonstrates the preferences of consumers.

According to Figure 2, distance credits are the most demanded credit type accounting for approximately $40 \%$ of all non-bank credits. In 2015, the amounts of distance credits have grown by EUR $29.41 \mathrm{mln}$ or $18.02 \%$ compared with 2012 with a considerable decrease in 2014 by $19.84 \%$ compared with the previous year. In general, the amounts of

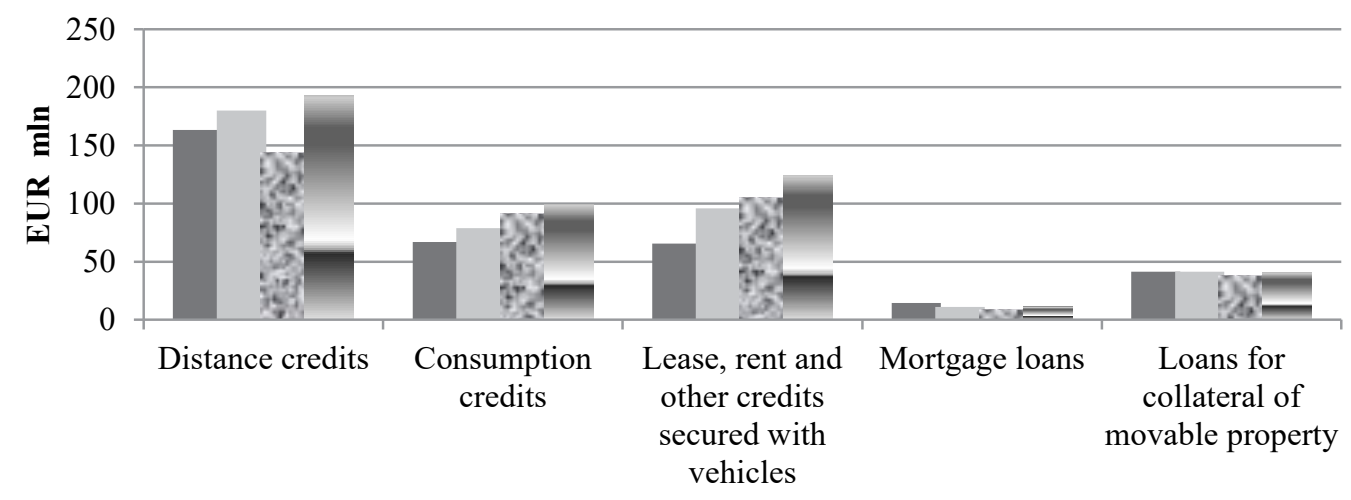

$\square 2012 \square 2013 \square 2014=2015$

Source: author's construction based on Patērētāju tiesību ..., 2016.

Figure 2. Breakdown of non-bank credits disbursed for the first time in Latvia between 2013 and 2015, EUR mln. 


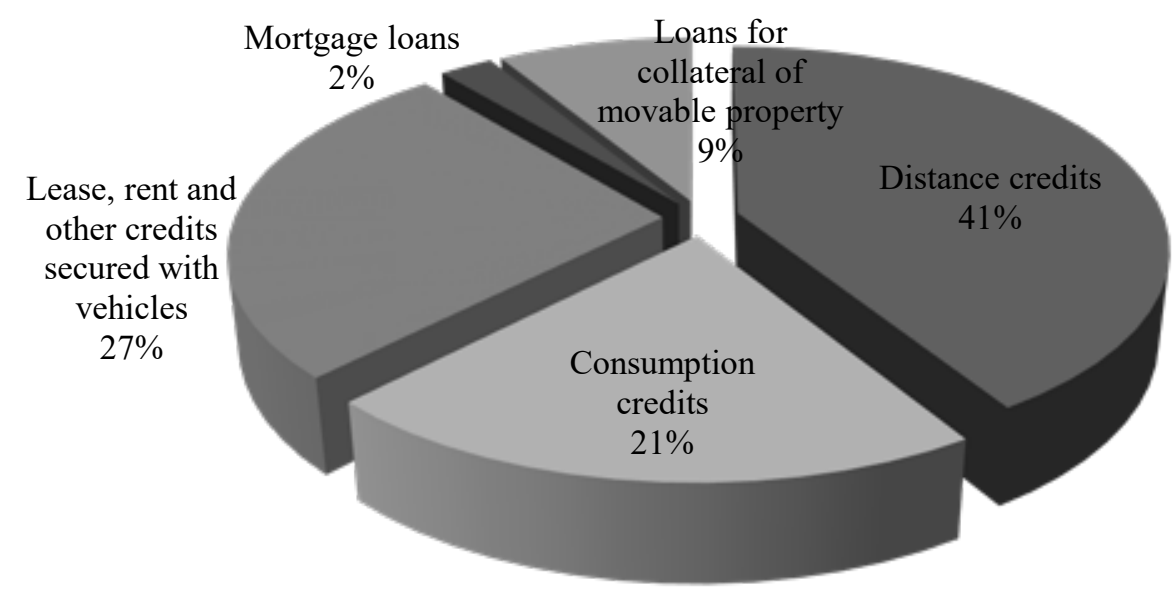

Source: author's construction based on Patērētāju tiesību ..., 2016.

Figure 3. Proportion of non-bank credits disbursed for the first time in Latvia in $2015, \%$.

disbursed distance credits have fluctuated during the analysed period. Steady growing trends between 2012 and 2015 are demonstrated by consumption credits and lease, rent and other credits secured with vehicles, where the credit amounts have increased by $47.99 \%$ and $89.79 \%$ respectively. Minor changes are observed for mortgage loans and loans for collateral of movable property.

In 2015, distance credits govern in all non-bank credits disbursed for the first time, since their share is $41 \%$, followed by lease, rent and other credits secured with vehicles $(27 \%)$, consumption credits $(21 \%)$ and loans for collateral of movable property $(9 \%)$. The smallest share is taken by mortgage loans $(2 \%)$. The shares of mortgage loans and lease, rent and other credits secured with vehicles in total nonbank credits have not changed in 2015 compared with the previous year; however changes relate with other types of credits, i.e. the share of distance credits has increased by 4 percentage points, while the shares of consumption credits and loans for collateral of movable property have decreased by 3 and 1 percentage points respectively (Figure 3).

In general, according to the Consumer Protection Rights Centre, demand for non-bank credits has not changed significantly; though, the increase goes for the number of rejected applications. The primarily reasons for rejections include incompliability of consumers with the criteria for crediting, for example, members of Latvian Association of Alternative Financial Services disburse credits only to people older than 20 years (Patērētāju tiesību..., 2016). There is a requirement to submit a proof of income if a credit amount exceeds EUR 427 or the maximum credit amount is not disbursed if a person borrows for the first time. The average credit amount has declined by approximately $10 \%$ and it is about EUR 160 due to the introduced requirements for the evaluation of consumers' solvency.

\section{Annual percentage rate of charge (APR)}

The annual percentage rate of charge (APR) is a very disputable issue when determining the price of non-bank credits, thus, it requires a more detailed study and interpretation. Historically, the formula for calculating the annual percentage rate of charge was introduced to facilitate the transparency and comparability of credit market and to increase the awareness of customers both consistent with the EU and national regulatory enactments. The necessity for the APR formula was based on long-term banking services and it has not been adjusted for short-term credits (up to one year). Therefore, the APR formula might be applied to compare traditional bank services; yet it may not be applied to draw a comparison between non-bank and traditional bank services. This instrument is inappropriate for the comparison of crediting products with the repayment term exceeding one year and those up to one year. Frequently, the APR for short-term credits is higher than for the long-term credits; though, in reality it may turn to be a cheaper credit instrument for a consumer. According to the PricewaterhouseCoopers, the APR is not an indicator to reflect the profitability for a customer in an individual situation (PricewaterhouseCoopers, 2013).

From the beginning of the harmonization process, it was considered that the total cost of credit should include all the costs that the consumer has to pay, including interest and other charges, and that these costs should be expressed in terms of an annual percentage rate of charge. It is this rate which provides consumers with a means of comparing credit across the EU. Hence, the APR are total credit costs expressed as annul interest of the total credit amount consistent 
The comparison between traditional bank and non-bank consumption credits based on the APR calculation

\begin{tabular}{|l|c|c|c|c|c|}
\hline Type of credit & $\begin{array}{c}\text { Traditional } \\
\text { bank } \\
\text { consumption } \\
\text { credit }\end{array}$ & $\begin{array}{c}\text { Non-bank } \\
\text { consumption } \\
\text { credit }-12 \\
\text { months }\end{array}$ & $\begin{array}{c}\text { Non-bank } \\
\text { consumption } \\
\text { credit }-6 \\
\text { months }\end{array}$ & $\begin{array}{c}\text { Non-bank } \\
\text { consumption } \\
\text { credit }-1 \\
\text { month }\end{array}$ & $\begin{array}{c}\text { Non-bank } \\
\text { consumption } \\
\text { credit - } 1 \text { day }\end{array}$ \\
\hline Principal credit amount, EUR & 1000 & 1000 & 1000 & 1000 & 1000 \\
\hline Repayment period, months & 36 & 12 & 6 & 1 & $1 / 30$ \\
\hline Interest rate per annum, \% & 10 & 10 & 10 & 10 & 10 \\
\hline $\begin{array}{l}\text { Advance payment of administrative } \\
\text { costs, EUR }\end{array}$ & 100 & 100 & 100 & 100 & 100 \\
\hline APR,\% & 36.68 & 28.41 & 44.04 & 131.00 & 251.74 \\
\hline Contributions, EUR & 1277.78 & 1160.49 & 1132.31 & 1109.17 & 1104.71 \\
\hline Total amount to be repaid, EUR & 277.78 & 160.49 & 132.31 & 109.17 & 104.71 \\
\hline Total overpaid amount, EUR & & & & & 1109.17 \\
\hline
\end{tabular}

Source: PricewaterhouseCoopers, 2013.

with the Directive 2008/48/EC requirements. The equation expressing the APR and the equivalence for a year's period between the existing credit and total value of the remaining credit and costs is as follows: (Cabinet Regulation..., 2016).

$$
\sum_{k=1}^{m} C_{k}(1+X)^{-t_{k}}=\sum_{l=1}^{m^{\prime}} D_{l}(1+X)^{-s_{l}}, \text { where }
$$

$X$ - annual percentage rate of charge; $m$ - number of the last drawdown; $k$ - number of a drawdown, thus, $1 \leq \mathrm{k} \leq \mathrm{m} ; C_{k}$ - amount of drawdown $\mathrm{k} ; t_{k}$ - interval, expressed in years and fractions of a year, between the date of the first drawdown and the date of each subsequent drawdown, thus $\mathrm{t} 1=0 ; m^{\prime}-$ number of the last repayment or payment of charges; $l$ - number of a repayment or payment of charges; $D_{l}$ - amount of a repayment or payment of charges; $s_{l}$ - interval, expressed in years and fractions of a year, between the date of the first drawdown and the date of each repayment or payment of charges (European Commission, 2013).

The APR formula is envisaged for credits with the repayment term being expressed in years or parts of the year $\left(t_{k}\right.$ and $\left.s_{1}\right)$, which is the basis for interest rates on consumption credits issued by banks. The formula allows expressing the repayment term in days, for example, 14 days are expressed as part of the year - 14/365; however, the formula is not specifically applicable for consumption credits with short repayment period. The APR includes total cost of the credit to the consumer such as interest, commissions, taxes and any other kind of fees which the consumer is required to pay in connection with the credit agreement and which are known to the creditor, except for notarial costs; costs in respect of ancillary services relating to the credit agreement, in particular insurance premiums, are also included if, in addition, the conclusion of a service contract is compulsory in order to obtain the credit or to obtain it on the terms and conditions marketed (Cabinet Regulation..., 2016). The APR does not reflect the actual amount of overcharge or the credit price - a credit with a high APR may cost cheaper for a consumer. Table 1 depicts the comparison between the traditional bank and non-bank consumption credit prices to show the inappropriateness of such comparison.

The audit company PricewaterhouseCoopers has developed this comparison to prove that the APR is not a desirable instrument to compare bank and nonbank credit services, since the APR amount differs for identical credit amounts with identical interest rate and advance payment but various repayment periods. The research author draws attention to the total overpaid amount, which is the highest for traditional bank consumption credits (EUR 277.78) with a repayment period of 36 months, while a similar nonbank consumer credit with the repayment term 1/30 of a month requires overpayment of EUR 104.71. This comparison is illogic, as in accordance with the data provided in Table 1, a credit with the highest APR costs much less for a consumer than a credit with the lowest APR. The basic determining factor is the period of credit repayment. 
The average weighted fixed interest rates (AWF) and annual percentage rates (APR) for non-bank credits in Latvia for the period 2013 - 2015, in December, \%

\begin{tabular}{|c|c|c|c|c|c|c|}
\hline & \multicolumn{2}{|c|}{2013} & \multicolumn{2}{|c|}{2014} & \multicolumn{2}{|c|}{2015} \\
\hline & AWF & APR & AWF & APR & AWF & APR \\
\hline Mortgage non-bank loans & 14.61 & - & 16.12 & - & 14.30 & - \\
\hline $\begin{array}{l}\text { Leasing and another loan secured with a vehicle } \\
\text { or other property }\end{array}$ & 32.54 & 41.71 & 40.54 & 50.87 & 31.87 & 43.20 \\
\hline \multicolumn{7}{|l|}{ Consumption credits } \\
\hline $\begin{array}{l}\text { repayment terms }-1 \text { payment with a period up } \\
\text { to } 14 \text { days }\end{array}$ & 378.85 & \multirow{2}{*}{789.37} & 396.24 & \multirow{2}{*}{857.40} & 245.92 & \multirow{2}{*}{234.80} \\
\hline $\begin{array}{l}\text { repayment terms }-1 \text { payment with a period } \\
\text { more than } 14 \text { days }\end{array}$ & 266.29 & & 396.24 & & 99.76 & \\
\hline repayment schedule and/or credit line & 35.29 & 90.59 & 41.96 & 102.88 & 31.93 & 64.68 \\
\hline \multicolumn{7}{|l|}{ Distance credits } \\
\hline $\begin{array}{l}\text { repayment terms - } 1 \text { payment with a period up } \\
\text { to } 14 \text { days }\end{array}$ & 248.98 & \multirow{2}{*}{255.30} & 240.94 & \multirow{2}{*}{228.09} & 230.26 & \multirow{2}{*}{210.50} \\
\hline $\begin{array}{l}\text { repayment terms }-1 \text { payment with a period } \\
\text { more than } 14 \text { days }\end{array}$ & 115.56 & & 110.39 & & 112.43 & \\
\hline repayment schedule and/or credit line & 76.61 & 162.87 & 82.43 & 162.24 & 77.77 & 123.20 \\
\hline Loans against pledge of movable property & 176.56 & - & 180.37 & - & 185.26 & - \\
\hline
\end{tabular}

Source: author's construction based on Patērētāju tiesību..., 2016.

Non-bank credit market is saturated and there is a fierce competition between non-bank crediting companies in terms of interest rates, crediting conditions and other factors. Non-bank credit companies apply two types of interest rates for their services: the average weighted interest rates (fixed and variable) and the annual percentage rate of charge. The average weighted fixed interest rates are considerably higher compared with the variable rates. The significant difference between the low interest rates on contracts with variable interest rate with the repayment period up to 1 year and the high interest rates on contracts with the fixed interest rate is determined by factors that the first type of contracts in most cases is concluded between consumers and non-bank crediting companies that have access to cheaper financial resources, in turn the second type of contracts is concluded between consumers and nonbank creditors to which financial resources are limited (they have to buy them for higher prices) and who, when concluding transactions, undertake greater risks, which later are featured in the borrowers' interest rates and credit amounts. Table 2 reflects the comparison between the average weighted fixed interest rates (AWF) and annual percentage rates (APR) for all types of non-bank credits in Latvia. The analysed period covers only 3 years, since the information on non-bank credit companies and services provided by them are gathered only from 2013 . The rates are compared for December following the principle that financial information is summarised at the end of the year; however, interest rates fluctuate throughout the year.

The highest interest rates both the average weighted interest rates and the annual percentage rates are observed for consumption credits and distance credits, followed by loans against pledge of movable property; while the lowest rates are for mortgage nonbank loans and leasing and another loans secured with a vehicle or other property. Interest rates for mortgage non-bank loans issued for the first time have declined to $14.30 \%$ in December 2015; the decline is by 1.82 percentage points compared with the respective period in 2014. The highest rate was observed in August 2014 (21.18\%), while the lowest one in August 2015 (14.26\%). The weighted average interest rate on mortgage loans with a variable rate is not evaluated because only one company disburses these loans for small amounts. Interest rates on loans against pledge of movable property have increased by 8.7 percentage points. In general, these credits gradually become more expensive at the almost constant number of new credit agreements and the balance of credit portfolio. The average weighted fixed interest rates for consumption credits with the repayment terms -1 payment with a period up to 14 days have decreased by 132.93 percentage points, these interest rates have experienced historically highest values $(402.70 \%$ in February 2015) and historically lowest values (245.92\% in December 2015). Consumption credits 
with the repayment terms - 1 payment with a period more than 14 days produce similar fluctuations; yet the decrease is more considerable compared with the credits to be repaid up to 14 days, i.e. 166.53 percentage points. According to the Consumer Protection Rights Centre, such a decrease may be related with the introduction of stricter restrictions for the operation of non-bank credit companies from 2016 (Patērētāju tiesību..., 2016); thus, companies ensured their crediting activities through offering much lower interest rates. Consumption credits with the repayment schedule or credit line are subject to the smallest fluctuations. The annual percentage rates for consumption credits show dramatic differences; here, rates are reflected for the repayment term more than 14 days. This group of credits has traditionally high interest rates and sensitivity towards periodic increases (additional costs etc.); thus the highest rate of $3400.52 \%$ was in July 2015 , while the lowest one $-234.80 \%$ in December 2015. Distance credits reflect the most moderate fluctuations through the whole analysed period with a decreasing trend till December 2015. It is impossible to unanimously interpret the reason for fluctuations and difference, since there are more than 50 non-bank credit companies providing alternative credits and each of them follow their own business terms and application of particular interest rates.

\section{Conclusions}

1. Non-bank credit companies without customer deposits have transformed the present credit market, since a number of new players entered the market testing new business and crediting models and providing solutions to credit-challenged customers.

2. The popularity of non-bank credits is still growing among consumers, since the total amounts of non-bank credits disbursed for the first time have increased by EUR 116.61 million or $33.18 \%$ for the period 2012 - 2015 with distance credits being the most demanded credit type accounting for approximately $40 \%$ of all non-bank credits.

3. The annual percentage rate of charge (APR) is not a desirable instrument to compare bank and nonbank credit services, since the APR amount differs for identical credit amounts with identical interest rates and advance payments but various repayment periods, as a credit with the highest APR may cost much less for a consumer than a credit with the lowest APR. The basic determining factor is the period of credit repayment.

4. The APR is higher as it includes total cost of the credit to the consumer such as interest, commissions, taxes and any other kind of fees which the consumer is required to pay in connection with the credit agreement and which are known to the creditor, except for notarial costs.

5. The comparison of the average weighted interest rates $(\mathrm{AWF})$ and the annual percentage rates of charge (APR) demonstrates that the highest rates are observed for consumption and distance credits with the repayment terms - 1 payment with a period up to and more than 14 days; while the lowest rates are determined for the mortgage nonbank loans.

6. Non-bank credit market is saturated and there is a fierce competition between non-bank crediting companies in terms of interest rates, crediting conditions and other factors; thus, the terms for licensing non-bank companies should envisage more detailed procedure for those companies which apply unfair treatment of consumers.

\section{References}

1. Cabinet Regulation No 245 (2011). Regulations Regarding the Procedures by Which a Special Permit (Licence) for the Provision of Consumer Credit Services Shall Be Issued, Re-Registered, Suspended and Cancelled and the State Fee for the Issue and Re-Registration of a Special Permit (Licence) Shall Be Paid, as well as the Requirements for a Capital Company for the Receipt of a Special Permit (Licence). Retrieved March 8, 2017, from: http://vvc.gov.lv/export/sites/default/docs/LRTA/MK_Noteikumi/Cab. Reg._No._245___Special_Permit_for_the_Provision_of_Consumer_Credit_Services.pdf.

2. Cabinet Regulation No 691 (2016). Noteikumi par patēēèāju kreditěšanu (Regulation on consumer crediting). Retrieved March 10, 2017, from: https://likumi.lv/ta/id/285975-noteikumi-par-pateretajakreditesanu. (in Latvian).

3. European Commission (2013). Study on the calculation of the annual percentage rate of charge for consumer credit agreements. Retrieved March 7, 2017, from: http:/ec.europa.eu/consumers/documents/ study_apr_2013_final.pdf.

4. Gambacort, L., \& Marqyes-Ibanez, D. (2011). The bank lending channel: lessons from the crisis Economic Policy 26 (66): 135 - 182. DOI: 10.1111/j.1468-0327.2011.00261.x.

5. Jagtiani, J., Lemieux, C. (2016). Small business lending after the financial crisis: a new competitive landscape for community banks. Economic Perspectives, Federal Reserve Bank of Chicago. Retrieved March 9, 2017, from: https://www.chicagofed.org/publications/.../2016/3-jagtiani-lemieux. 
6. Mirea, M., \& Aivaz, K. (2014). Analysis of the nonbank, non-government customers credits, in territorial profile. Retrieved March 3, 2017, from: http://ec.europa.eu/consumers/financial_services/consumer_ credit_directive/index_en.htm.

7. Parliament of the Republic of Latvia (1999). Consumer Rights Protection Law. Retrieved March 10, 2017, from: http://vvc.gov.lv/export/sites/default/docs/LRTA/Likumi/Consumer_Rights_Protection_Law.pdf.

8. Patērētāju tiesību aizsardzības centrs (2016). Pārskats par nebanku patēēētāju kréditēšanas tirgus darbību 2015. gada (Report on non-bank consumer creditor activities in 2015). Riga. (in Latvian).

9. PricewaterhouseCoopers (2013). Ziņojums par ārvalstu pieredzi gada procentu likmes izmantošana un nosakot ierobežojumus nebanku kreditěšanā (Report on foreign experience in the application of annual percentage rate of charge and setting restrictions for non-bank crediting). Retrieved March 9, 2017, from: www.lafpa.lv/download/file/36672874af2b158e479a68d7721dd7fd.pdf?id=16. (in Latvian).

10. Reifner, Ud., Clerc-Renaud, S., \& Knobloch, M. (2010). Study on interest rate restrictions in the EU. Final Report. Retrieved March 3, 2017, from: http://ec.europa.eu/internal_market/finservices-retail/docs/credit/ irr_report_en.pdf.

11. Robert, Y., Scott, F., \& Glennon, D. (2008). Commercial lending distance and historically underserved areas. Journal of Economics and Business 60, 149 - 164. 